\title{
PENERAPAN HAK-HAK TERSANGKA DALAM PROSES PENYIDIKAN DIHUBUNGKAN DENGAN KETERBUKAAN INFORMASI DALAM PERSPEKTIF HAK ASASI MANUSIA
}

\author{
Oleh : ANDA HERMANA, S.H., M.H. ${ }^{*}$
}

\begin{abstract}
The suspect has certain rights which must be given in accordance with the Act and are guaranteed given these rights in accordance with human rights. Right to information is a human right . Public body is obliged to guarantee these rights in accordance with Law No. 14 of 2008 on Public Information.
\end{abstract}

\section{ABSTRAK}

Tersangka mempunyai hak-hak tertentu yang harus diberikan menurut Undang-undang dan dijamin diberikannya hak-hak tersebut sesuai dengan hak asasi manusia. Hak mendapatkan informasi merupakan hak asasi manusia. Badan publik berkewajiban menjamin hak-hak tersebut sesuai dengan Undang-Undang Nomor 14 Tahun 2008 tentang Keterbukaan Informasi Publik.

\section{PENDAHULUAN}

$$
\text { Menurut Pasal } 1 \text { ayat (1) }
$$

Undang-undang Nomor 39 tahun 1999 tentang Hak Asasi Manusia serta Undang-undang Nomor 26 tahun 2000 tentang Pengadilan HAM, Hak Asasi Manusia adalah seperangkat hak yang melekat pada hakikat dan keberadaan manusia sebagai makhluk Tuhan Yang Maha Kuasa dan merupakan anugerahNya yang wajib dihormati, dijunjung tinggi dan dilindungi oleh negara, hukum, pemerintah dan setiap orang demi kehormatan serta perlindungan harkat dan martabat manusia. Sebagaimana penulis yang di teliti bahwa Hak Asasi Manusia ini sangat erat kaitannya dengan masalah penyidikan tindak pidana karena dalam penyidikan penyidik di tuntut untuk menggali keterangan dari tersangka dengan menjunjung tinggi harkat dan martabat sebagai manusia serta memberikan apa yang menjadi hak dari tersangka.

Adapun dalam Kitab Undangundang Hukum Acara Pidana bahwa kita akan melihat apa yang menjadi hak-hak dari tersangka yaitu :

1. Hak Prioritas Penyelesaian Perkara (Pasal 50 KUHAP)

2. Hak Persiapan Pembelaan (Pasal 51 KUHAP)

3. Hak Memberi Keterangan Secara Bebas (Pasal 52 KUHAP)

4. Hak untuk Mendapatkan Juru Bahasa (Pasal 53 KUHAP)

5. Hak Mendapatkan Bantuan Hukum (Pasal 54-56 KUHAP)

6. Hak menghubungi penasehat hukum (Pasal 57 KUHAP)

1. 
7. Hak kunjungan oleh dokter pribadi (Pasal 58 KUHAP)

1. Hak

diberitahu hubungan/kunjungan keluarga dan sanak keluarga (Pasal 5961 KUHAP)

2. Hak berkirim dan menerima surat (Pasal 62 KUHAP) diajukan saksi ade charge dan saksi ahli (Pasal 58 KUHAP)

3. Hak tidak dibebani kewajiban pembuktian (Pasal 66 KUHAP)

4. Hak banding dan kasasi (Pasal 67 jo pasal 244 KUHAP)

5. Hak peninjauan kembali putusan yang telah berkekuatan hukum tetap (Pasal 263 KUHAP)

\section{TINJAUAN PUSTAKA}

A. Tinjauan tentang Keterbukaan Informasi

Setiap berhak untuk berkomunikasi dan memperoleh informasi untuk mengembangkan pribadi dan lingkungan sosialnya, serta berhak untuk mencari, memperoleh, memiliki, dan menyimpan informasi dengan menggunakan segala jenis saluran yang tersedia. Atas dasar konstitusi tersebut Negara memberikan jaminan terhadap semua orang dalam memperoleh informasi dan dijabarkan melalui pembentukan Undang-Undang Nomor 14 Tahun 2008 tentang Keterbukaan Informasi Publik yang telah disahkan dan diundangkan pada tanggal 30 April 2008.

Salah satu wujud penyelenggaraan Negara yang terbuka adalah di implemetasikannya keterbukaan informasi publik melalui penggunaan hak publik untuk memperoleh informasi yang berdasar dengan ketentuan peraturan perundangundangan.

Hak atas informasi menjadi sangat penting dalam upaya menjadikan proses keterbukaan penyelenggara Negara untuk terbuka kepada publik sehingga apa yang dilakukan oleh penyelenggara atas kerja-kerja penyelenggaraan Negara dapat diterima dan dipertanggungjawabkan kepada publik.

Informasi publik merupakan salah satu upaya untuk mengembangkan masyarakat. Informasi, dan keterbukaan informasi publik merupakan sarana dalam mengoptimalkan pengawasan publik terhadap penyelenggaraan negara dan Badan Publik untuk mewujudkan penyelenggaraan negara yang baik.

Informasi Publik adalah informasi yang dihasilkan, disimpan, dikelola, 
dikirim, dan/atau diterima oleh suatu badan publik yang berkaitan dengan penyelenggara dan penyelenggaraan negara dan/atau penyelenggara dan penyelenggaraan badan publik lainnya yang sesuai dengan Undang-Undang ini serta informasi lain yang berkaitan dengan kepentingan publik.

Setiap Informasi Publik bersifat terbuka dan dapat diakses oleh setiap Pengguna Informasi dengan cepat dan tepat waktu, biaya ringan, dan cara sederhana. Pengecualiannya adalah terhadap Informasi publik yang bersifat rahasia sesuai dengan Undang-Undang, kepatutan, dan kepentingan umum didasarkan pada pengujian tentang konsekuensi yang timbul apabila suatu informasi diberikan kepada masyarakat.

Dalam era Keterbukaan Informasi Publik, Polri sebagai salah satu badan publik, dituntut untuk lebih meningkatkan kinerjanya secara optimal dan profesional yang diharapkan dapat memberikan pelayanan informasi kepada publik secara cepat, murah, transparan dan akuntabel. Pasal 2 UU No. 14 tahun 2008 tentang Keterbukaan Informasi Publik, menentukan Asasasas yang menyebutkan :

(1) Setiap Informasi Publik bersifat terbuka dan dapat diakses oleh setiap Pengguna Informasi Publik.
(2) Informasi Publik yang dikecualikan bersifat ketat dan terbatas.

(3) Informasi Publik yang dikecualikan bersifat rahasia sesuai dengan Undang-Undang, kepatutan, dan kepentingan umum didasarkan pada pengujian tentang konsekuensi yang timbul apabila suatu informasi diberikan kepada masyarakat serta setelah dipertimbangkan dengan saksama bahwa menutup Informasi Publik dapat melindungi kepentingan yang lebih besar daripada membukanya atau sebaliknya.

Seiring dengan tuntutan masyarakat yang semakin kompleks dan kritis terhadap jasa pelayanan informasi tersebut maka dibutuhkan kesiapan secara menyeluruh, salah satu bentuk daripada kesiapan tersebut adalah penyiapan Pejabat Pengelola Informasi dan Dokumentasi (PPID) yang bertanggung jawab di bidang penyimpanan, pendokumentasian, penyediaan dan atau pelayanan informasi.

Untuk mengimplementasikan tujuan tersebut Div Humas Mabes Polri telah membentuk Pejabat Pengelola Informasi dan Dokumentasi (PPID) yang bertanggung jawab di bidang penyimpanan, pendokumentasian, 
penyediaan, dan/atau pelayanan informasi. Dalam melaksanakan tugas dan tanggung jawabnya PPID Mabes Polri berwewenang untuk Mengkoordinasikan setiap unit/satuan kerja di badan publik dalam melaksanakan pelayanan informasi public; (b) Memutuskan suatu informasi dapat diakses publik atau tidak; (c) Menolak permohonan informasi secara tertulis apabila informasi yang dimohon termasuk informasi yang dikecualikan/ rahasia dengan disertai alasan serta pemberitahuan tentang hak dan cara bagi pemohon untuk mengajukan keberatan atas penolakan tersebut; (d) Menugaskan pejabat fungsional dan/atau petugas informasi di bawah wewenang dan koordinasinya untuk membuat. Informasi publik di lingkungan Polri merupakan informasi yang dihasilkan, disimpan, dikelola, dikirim, atau diterima, yang berkaitan dengan kegiatan Polri dan Informasi publik tersebut, berdasarkan kriterianya terdiri dari:

1) informasi yang dikecualikan untuk dipublikasikan meliputi informasi yang dapat menghambat proses penyelidikan dan penyidikan suatu tindak pidana, mengungkapkan data intelijen kriminal yang berhubungan dengan pencegahan dan penanganan segala bentuk kejahatan transnasional, membahayakan keselamatan dan kehidupan penyidik dan keluarganya, membahayakan keamanan peralatan, sarana dan prasarana penyidik Polri (seperti: identitas saksi, barang bukti, dan tersangka, modus operandi tindak pidana, motif dilakukan tindak pidana, jaringan pelaku tindak pidana, turunan berita acara pemeriksaan tersangka, isi berkas perkara dan taktis dan teknis penyelidikan dan penyidikan).

2) informasi yang bukan dikecualikan meliputi daftar pencarian orang (DPO), rencana anggaran yang akan dikeluarkan dalam proses penyidikan tindak pidana, surat pemberitahuan perkembangan hasil penyidikan (SP2HP), pertanggungjawaban keuangan yang digunakan dalam proses penyidikan tindak pidana, hasil proses penyidikan tindak pidana yang berkaitan dengan uang dan barang yang telah disita dan informasi lainnya yang ditetapkan oleh pimpinan Polri.

3) informasi yang wajib diumumkan secara serta merta yang dapat mengancam hajat hidup orang banyak dan ketertiban masyarakat meliputi unjuk rasa yang berpotensi anarkis, kerusuhan massa, bencana alam yang berdampak luas, peristiwa 
yang meresahkan masyarakat, kecelakaan moda transportasi yang menarik perhatian masyarakat dan ancaman/peledakan bom

4) informasi yang wajib tersedia setiap saat antara lain meliputi peraturan kepolisian, kesepakatan bersama, prosedur pelayanan Surat Izin Mengemudi (SIM), Surat Tanda Nomor Kendaraan (STNK), Tanda Nomor Kendaraan Bermotor (TNKB), dan Buku Pemilik Kendaraan Bermotor (BPKB), prosedur pelayanan Surat Keterangan Catatan Kepolisian (SKCK), prosedur pemberitahuan penyampaian pendapat di muka umum, prosedur pelayanan perizinan senjata api dan bahan peledak, prosedur pelayanan penerbitan dokumen orang asing, prosedur pelayanan pemberian bantuan kepolisian berupa pengawalan, pengamanan dan pelaporan gangguan kamtibmas; dan pengadaan barang dan jasa di lingkungan Polri.

5) informasi yang wajib disampaikan secara berkala antara lain meliputi laporan rencana kerja kesatuan Polri tahunan, laporan akuntabilitas kinerja instansi pemerintah (LAKIP), data statistik gangguan Kamtibmas setiap 3 (tiga) bulanan, 6 (enam) bulanan dan tahunan serta seleksi penerimaan calon anggota Polri meliputi Akademi Kepolisian (Akpol).

\section{B. Tinjauan mengenai Hak Asasi Manusia}

Pembahasan konflik antara Teori Hukum Kodrat dan Positivisme Hukum, menghasilkan kesimpulan bahwa walaupun bidang hukum harus dibedakan dari bidang moral, namun hukum tak dapat mempertahankan legitimasinya kalau dilepaskan dan tuntutan-tuntutan dasar wujud kehidupan yang adil dan sesuai dengan martabat manusia. (Franz MagnisSuseno, 1988 : 121). Maksud untuk menjamin keadilan, kebebasan, dan kesetiakawanan sosial termasuk hakikat hukum. Sarana untuk mewujudkan maksud itu adalah hak-hak asasi manusia. Hak-hak asasi itulah yang menjadi pokok bahasan bab ini. (Budiarjo, 1977 : 121).

Pemahaman akan hak-hak asasi manusia dimaksudkan adalah hak-hak yang dimiliki manusia bukan karena diberikan kepadanya oleh masyarakat jadi bukan berdasarkan hukum positif yang berlaku, melainkan berdasarkan martabatnya sebagai manusia. Manusia memilikinya karena ia manusia. Dalam paham hak asasi manusia termasuk bahwa hak itu tidak dapat dihilangkan atau dinyatakan tidak berlaku oleh negara. Negara dapat saja 
tidak mengakui hak-hak asasi itu. Dengan demikian hak-hak asasi tidak dapat dituntut di depan hakim. Tetapi, dan itulah yang menentukan, hak-hak itu tetap dimiliki. Dan karena itu hak-hak asasi seharusnya diakui. Tidak mengakui hak-hak yang dimiliki manusia sebagai manusia itu menunjukkan bahwa dalam negara itu martabat manusia belum diakui sepenuhnya. Itulah paham tentang hak-hak asasi manusia.

Melalui hak asasi itu tuntutan moral yang prapositif dapat direalisasikan dalam hukum positif. Di satu pihak hak-hak asasi manusia mengungkapkan tuntutan-tuntutan dasar martabat manusia, jadi apa yang diperjuangkan oleh Teori Hukum Kodrat. (Heidelmeyer : 1988 : 122). Tetapi di lain pihak, karena tuntutan-tuntutan itu dirumuskan sebagai hak atau kewajiban yang konkret dan operasional, tuntutantuntutan itu dapat dimasukkan ke dalam hukum positif sebagai norma-norma dasar dalam arti bahwa semua norma hukum lainnya tidak boleh bertentangan dengan mereka. Dengan demikian tuntutan Positivisme Hukum terpenuhi bahwa hanya norma-norma hukum positif boleh dipergunakan oleh hakim untuk mengambil keputusan. Dari situ dapat ditarik kesimpulan bahwa semakin banyak dari tuntutan-tuntutan dasar keadilan dan martabat manusia dimasukkan sebagai hak asasi ke dalam hukum positif. semakin terjamin juga bahwa hukum itu memang adil dan sesuai dengan martabat manusia.

Paham hak-hak asasi manusia ini menimbulkan banyak pertanyakan: tentang kedudukan hak asasi sebagai hak, tentang apakah dapat dipaksakan, tentang dasar perumusan hak-hak asasi tertentu, tentang universalitas dan relativitasnya, terutama apakah paham ini 'berlaku' secara transtruktural tentang perubahan dan perkembangannya. Pertanyaan-pertanyaan itu sudah dikemukakan hampir sejak paham hak asasi lahir. Yang barangkali paling mengesankan ialah bahwa paham ini tidak dapat dimatikan; bahwa semakin banyak sistem kekuasaan, dengan rela atau ditekan oleh masyarakat, mengakui semakin banyak hak asasi; bahwa tidak ada sistem kekuasaan yang masih dapat bersikap masa bodoh terhadap hak-hak asasi manusia.

\section{PEMBAHASAN}

Titik pangkal pemeriksaan di hadapan penyidik ialah tersangka, dari dialah diperoleh keterangan tentang peristiwa pidana yang sedang diperiksa. Akan tetapi, sekalipun tersangka yang menjadi titik tolak pemeriksaan, terhadapnya harus diberlakukan asas 
akusatur. Tersangka harus ditempatkan pada kedudukan manusia yang memiliki harkat martabat. Dia harus dinilai sebagai subjek, bukan sebagai objek. Yang diperiksa bukan manusia tersangka. Perbuatan tindak pidana yang dilakukannya lah yang menjadi objek pemeriksaan. Ke arah kesalahan tindak pidana yang dilakukan pemeriksaan ditujukan. Tersangka harus dianggap tak bersalah, sesuai dengan prinsip hukum "praduga tak bersalah" (presumption of innocent) sampai diperoleh putusan pengadilan yang telah berkekuatan tetap.

Pada pemeriksaan tindak pidana, tidak selamanya hanya tersangka saja yang harus diperiksa. Adakalanya diperlukan pemeriksaan saksi atau ahli, demi untuk terang dan jelasnya peristiwa pidana yang disangkakan. Namun, sedangkan kepada tersangka harus ditegakkan perlindungan harkat martabat dan hak-hak asasi, kepada saksi dan ahli, harus juga diperlakukan dengan cara yang berperikemanusiaan dan beradab.

Sehubungan

dengan

pemeriksaan tersangka, Undangundang telah memberi beberapa hak perlindungan terhadap hak asasinya serta perlindungan terhadap haknya untuk mempertahankan kebenaran dan pembelaan diri seperti yang diatur pada
Bab VI, Pasal 50 sampai Pasal 68 KUHAP seperti yang telah di kemukakan di atas. Tetapi penulis pada pembahasan ini akan mengemukakan bagaimana hak-hak tersangka pada tingkat penyidikan saja.

Diantara hak-hak tersangka pada tingkat penyidikan adalah Hak tersangka untuk segera mendapat pemeriksaan oleh penyidik. Apa arti "segera", undang-undang tidak menjelaskan lebih lanjut. Akan tetapi, dari pengertian bahasa barangkali "secepat mungkin" atau "sekarang juga" tanpa menunggu lebih lama. Motivasi pemberian hak untuk segera diperiksa dapat dibaca pada penjelasan Pasal 50 antara lain:

a. Untuk menjauhkan kemungkinan terkatung-katung nasib orang yang disangka.

b. Jangan sampai lama tidak mendapat pemeriksaan, sehingga dirasakan tidak ada kepastian hukum, terjadinya perlakuan sewenangwenang dan ketidakwajaran.

c. Demi mewujudkan asas peradilan sederhana, cepat, dan biaya ringan. Sungguh idealistic apa yang hendak dijangkau Pasal 50 tersebut, namun masih dapat dipertanyakan, apakah ini hanya merupakan impian. Pengalaman silam terlampau pahit, sehingga motivasi idealisms yang terkandung pada Pasal 50, masih diragukan dalam 
pelaksanaan.

\section{Berdasarkan}

pengamatan

penulis, dapat dilihat bahwa hak tersangka ini tidak sepenuhnya dilaksanakan karena tersangka kadang tidak langsung dan serta merta diperiksa tetapi dia dimasukkan di sel tahanan sehingga dikhawatirkan mendapat perlakuan yang tidak wajar dari penghuni sel yang telah terdahulu. Makanya sering terjadi perkelahian di dalam sel apabila ada tahanan yang baru atau perilaku yang tidak wajar dari tahanan yang lain.

Salah satu hal yang paling penting untuk diingat penyidik, sejak permulaan pemeriksaan sampai selesai, penyidik harus berdiri di atas landasan prinsip hukum "praduga tak bersalah". Yakni harus mempergunakan sistem pemeriksaan "akulsatur", di mana si tersangka diproyeksikan sebagai subjek hukum dan bukan sebagai objek pemeriksaan. Yang menjadi objek pemeriksaan adalah kesalahan atau perbuatan yang disangkakan kepada tersangka.

Jawaban atau keterangan yang diberikan tersangka kepada penyidik, diberikan tanpa tekanan dari siapa pun juga dan dengan bentuk apa pun juga. Kita terkesan dan sangat setuju dengan ketentuan Pasal 117 KUHAP. Tersangka dalam memberikan keterangan harus "bebas" berdasar "kehendak" dan "kesadaran" nurani. Tidak boleh dipaksa dengan cara apa pun baik penekanan fisik dengan tindakan kekerasan dan penganiayaan, maupun dengan tekanan dari penyidik maupun dari pihak luar.

Mengenai jaminan pelaksanaan Pasal 117 KUHAP tersebut, tidak ada sanksinya. Satu-satunya jaminan untuk tegaknya ketentuan Pasal 117 KUHAP ialah melalui Praperadilan, berupa pengajuan gugatan ganti rugi atas alasan pemeriksaan telah dilakukan tanpa alasan yang berdasarkan undangundang. Akan tetapi, hal ini kurang efektif, karena sangat sulit bagi seorang tersangka membuktikan keterangan yang diberikan dalam pemeriksaan adalah hasil paksaan dan tekanan. Kontrol yang tepat untuk menghindari terjadinya penekanan atau ancaman dalam pemeriksaan penyidikan ialah kehadiran penasihat hukum mengikuti jalannya pemeriksaan. Tapi oleh karena Pasal 115 KUHAP hanya bersifat fakultatif, peran pengawasan yang diharapkan dari para penasihat hukum dalam pemeriksaan penyidikan, sangat terbatas, dan semata-mata sangat tergantung dari belas kasihan pejabat penyidik untuk memperbolehkan atau mengizinkannya. 
Bagaimana jika ternyata keterangan yang diberikan tersangka yang dituangkan dalam berita acara pemeriksaan adalah hasil pemerasan, tekanan, ancaman, atau paksaan? Keterangan yang diperoleh dengan cara seperti ini, "tidak sah". Cara yang dapat ditempuh untuk menyatakan keterangan itu tidak sah, dengan jalan mengajukan ke Praperadilan atas alasan penyidik telah melakukan cara-cara pemeriksaan tanpa alasan yang berdasarkan undangundang, dalam arti pemeriksaan telah dilakukan dengan ancaman kekerasan atau penganiayaan dan sebagainya. Apabila Praperadilan mengabulkan, berarti telah membenarkan adanya cara-cara pemaksaan dalam pemeriksaan.

Hal ini sangat berhubungan dengan hak asasi manusia dimana tercantum dalam Undang-undang Dasar 1945 Pasal 28D Ayat (1) yaitu setiap orang berhak atas pengakuan, jaminan, perlindungan, dan kepastian hukum yang adil serta perlakuan yang sama dihadapan hukum. Juga Pasal 28G Ayat (2) yaitu setiap orang berhak untuk bebas dari penyiksaan atau perlakuan yang merendahkan derajat martabat manusia dan berhak memperolah suaka politik dari negara lain. Serta Pasal 281 ayat (1) yaitu hak untuk hidup, hak untuk tidak disiksa, hak kemerdekaan pikiran dan hati nurani, hak beragama, hak untuk tidak diperbudak, untuk diakui sebagai pribadi dihadapan hukum dan hak untuk tidak dituntut atas dasar hukum yang berlaku surut, adalah hak asasi manusia yang tidak dapat dikurangi dalam keadaan apa pun. Pasal 28J ayat (1) setiap orang wajib menghormati hak asasi manusia orang lain dalam tertib kehidupan bermasyarakat, berbangsa dan bernegara.

Hak lain yang berhubungan dengan pemeriksaan dalam tingkat penyidikan adalah hak mendapatkan informasi yang sejelas-jelasnya baik oleh tersangka, keluarga tersangka, korban ataupun juga keluarga korban. Hal ini tercantum dalam Pasal 14 Undang-undang Nomor 39 Tahun 1999 yang menyebutkan bahwa :

(1) Setiap orang berhak untuk berkomunikasi dan memperoleh informasi yang diperlukan untuk mengembangkan pribadi dan lingkungannya.

(2) Setiap orang berhak untuk mencari, memperoleh, memiliki, menyimpan, mengolah, dan menyampaikan informasi dengan menggunakan segala jenis sarana yang tersedia. 
Peraturan lain menyebutkan yaitu di dalam Peraturan Kapolri Nomor 8 Tahun 2009 tentang Implementasi Prinsip dan standar Hak Asasi Manusia dalam Penyelenggaraan Tugas Kepolisian Negara Republik Indonesia, Pasal 5 huruf $z$ yang berbunyi bahwa hak berkomunikasi dan memperoleh informasi merupakan instrumen perlindungan HAM dalam melaksanakan tugas kepolisian berdasarkan Undangundang Dasar 1945.

Sebagai badan publik kepolisian berkewajiban pula memberikan informasi dan menyediakan informasi sesuai uraian di atas karena informasi merupakan hak setiap orang untuk mendapatkannya dalam keadaan bagaimanapun disini jelas termasuk orang yang sedang disidik juga keluarga, korban dan keluarga korban. Sebagai implementasi dari Undangundang Dasar 1945 juga dari Undangundang Nomor 39 Tahun 1999 Pasal 14 maka diundangkan Undang-undang Nomor 14 Tahun 2008 tentang Keterbukaan Informasi Publik. Diantaranya adalah Pasal 7 Ayat (1) bahwa badan publik wajib menyediakan, memberikan dan/atau menerbitkan informasi publik yang ada di bawah kewenangannya kepada pemohon informasi publik, selain informasi yang dikecualikan sesuai dengan ketentuan.
Pasal 17 Undang-undang Nomor 14 Tahun 2008 menyatakan :"Setiap Badan Publik wajib membuka akses bagi setiap pemohon informasi publik untuk mendapatkan informasi publik, kecuali :

a. Informasi publik yang apabila dibuka dapat menghambat proses penegakan hukum yaitu informasi yang dapat :

1. Menghambat proses penyelidikan dan penyidikan suatu tindak pidana;

2. Mengungkap identitas informan, pelapor, saksi dan/atau korban yang mengetahui adanya tindak pidana;

3. Mengungkapkan data intelijen kriminal dan rencana-rencana yang berhubungan dengan pencegahan dan penanganan segala bentuk kejahatan transnasional;

4. Membahayakan keselamatan dan kehidupan penegak hukum dan/atau keluarganya;

5. Membahayakan peralatan, sarana, dan/atau prasarana penegak hukum. "

Dari pasal tersebut di atas kita dapat melihat bawa kepolisian sebagai badan publik wajib menyediakan dan memberikan informasi kepada publik yang membutuhkan informasi, tetapi pemberian informasi itu di batasi sesuai dengan pasal 17 diatas.

Salah satu cara yang sangat tepat pada perkembangan zaman 
modern sekarang ini adalah pelayanan informasi melalui internet, dalam Pasal 29 Peraturan Kapolri Nomor 16 Tahun 2010 menyebutkan tentang tata cara penyampaian informasi publik yaitu:

Penyampaian informasi publik dalam bentuk :

a. Pemberian informasi dan data secara langsung

b. Akses informasi dan data melalui teknologi informasi dan komunikasi

c. Media cetak dan elektronik.

Selanjutnya peraturan lain untuk menjamin terselenggaranya hak tersangka mendapatkan informasi terutama dalam proses penyidikan yaitu dengan dikeluarkannya Peraturan Kepolisian Negara Republik Indonesia Nomor 21 Tahun 2011 tentang Sistem Informasi Penyidikan. Dalam peraturan ini di juga sebutkan tentang prinsipprinsip penyelenggaraan sistem informasi penyidikan dimana disebutkan dalam Pasal 3 yaitu ;

Prinsip-prinsip peraturan ini, meliputi ;

a. Transaparansi yaitu dalam pelayanan informasi penyidikan wajib dilaksanakan secara jelas dan terbuka;

b. Akuntabel, yaitu setiap kegiatan dalam pelayanan informasi penyidikan harus dapat dipertanggungjawabkan;

c. Proporsionalitas, yaitu setiap kegiatan dalam pelayanan informasi penyidikan harus memperhatikan keseimbangan antara hak dan kewajiban

d. Mudah, cepat, dan akurat yaitu setiap kegiatan dalam informasi penyidikan harus dilksanakan tepat waktu, disajikan dengan lengkap, mudah diakses dan aktual.

\section{Penutup}

Tersangka mempunyai hak-hak yang harus diberikan kepadanya setara dengan hak asasi manusia. Diantaranya hak yang berhubungan dengan pemeriksaan dalam tingkat penyidikan adalah hak mendapatkan informasi yang sejelas-jelasnya baik oleh tersangka, keluarga tersangka, korban ataupun juga keluarga korban. Mendapatkan informasi merupakan hak setiap orang dan ini merupakan Hak Asasi Manusia tetapi tidak semua orang mau di informasikan misalkan seseorang yang dalam sebagai status tersangka, dia sebenarna tidak mau di informasikan kepada publik tetapi dengan adanya Undang-undang keterbukaan informasi merupakan kewajiban bagi badan publik untuk menginformasikan semua kegaiatan yang dilakukan oleh badan publik kepada publik secara terbuka.

\section{DAFTAR PUSTAKA}

M. Yahya Harahap, Pembahasan Permasalahan Dan PEnerapan KUHAP Penyidikan dan 
Penuntutan, Edisi Kedua, Sinar Grafika, 2000, Jakarta.

Martiman Prodjohamodjojo, Kedudukan

Tersangka dan Terdakwa dalam

Pemeriksaan, Ghalia Indonesia, Jakarta, 1989.

Kedudukan Tersangka dan

Terdakwa Dalam Pemeriksaan, Ghalia Indonesia, Jakarta, 1989.

P.A.F. Lamintang, Dasar-dasar Hukum Pidana Indonesia, Citra Aditya Bakti, Bandung, 1997.

Franz Magnis-Suseno, Etika Politik (Prinsip-prinsip Moral Dasar Kenegaraan Modern), PT Gramedia, Jakarta, 1988.

Padmo Wahyono, Masalah Ketatanegaraan Indonesia Dewasa Ini, Ghalia Indonesia, Jakarta, 1984.

Kuntjoro Purbopranoto, Hak-hak Asasi Manusia dan Pancasila Dasar Negara Republik Indonesia, Jakarta, 1953.

\section{Perundang-Undangan}

Undang-undang Dasar 1945.

Undang-undang Nomor 1 Tahun 1946 tentang Kitab Undang-undang Hukum Pidana.

Undang-undang Nomor 8 Tahun 1981 tentang Kitab Undang-undang Hukum Acara Pidana.

Undang-undang Nomor 14 Tahun 2008 tentang Keterbukaan Informasi Publik.

Undang-undang Nomor 39 Tahun 1999 tentang Hak Asasi Manusia.
Peraturan Kepala Kepolisian Negara Republik Indonesia Nomor 8.

Tahun 2009 tentang Implementasi Prinsip dan Standar HAM dalam Penyelenggaraan Tugas Kepolisian Negara Republik Indonesia.

Peraturan Kepala Kepolisian Negara Republik Indonesia Nomor 16 Tahun 2010 tentang Tata Cara Pelayanan Informasi Publik di Lingkungan Kepolisian Negara Republik Indonesia.

Peraturan Kepala Kepolisian Negara Republik Indonesia Nomor 21 Tahun 2011 tentang Sistem Informasi Penyidikan.

Peraturan Kepala Kepolisian Negara Republik Indonesia Nomor 14 Tahun 2012 tentang Manajemen Pendidikan Tindak Pidana.

Standar Operating Procedure tentang Tata Cara Pelayanan Informasi. 
